\title{
ANTI-ATHEROSCLEROTIC ACTIVITY OF ELAEOCARPUS GANITRUS ROXB. IN CHOLESTEROL-FED RABBITS
}

\author{
PRATIBHA K JAIN, PRIYANKA SHARMA, SURESH C JOSHI*
}

Department of Zoology, Reproductive Toxicology Unit, Center for Advanced Studies, University of Rajasthan, Jaipur - 302 055, Rajasthan, India. Email: s_c_joshi2003@rediffmail.com

Received: 20 May 2017, Revised and Accepted: 15 August 2017

\section{ABSTRACT}

Objectives: Atherosclerosis was experimentally induced in New Zealand white male rabbits by cholesterol feeding for 120 days for investigating effects of 70\% ethanolic Elaeocarpus ganitrus seed extract (EEGS) against atherosclerosis.

Methods: Anti-atherosclerotic activity of E. ganitrus extract was evaluated at a dose level of 250 and $500 \mathrm{mg} / \mathrm{kg}$ of body weight (p.o). On $121^{\text {st }}$ day, the animals were sacrificed to collect the aorta for determining tissue lipid profile, antioxidant parameters, and histopathological changes. One-way ANOVA followed by Tukey's multiple comparison test was used for the statistical analysis.

Results: Aorta of cholesterol-fed rabbits for 120 days showed marked elevation in total cholesterol, triglycerides, and phospholipids. EEGS extract treatment significantly $(\mathrm{p} \leq 0.01, \leq 0.001)$ corrected disturbed lipid profile in cholesterol-fed rabbits in a dose-dependent manner during the 60 days of the treatment period. A significant reduction in lipid peroxidation and a considerable raise in glutathione, catalase, and superoxide dismutase levels $(p \leq 0.01, \leq 0.001)$ were accompanied by post-treatment with EEGS extract to cholesterol-fed rabbits. The histopathological modifications such as accumulation of foam cells, atheromatous plaque formation, and lumen size reduction supported the successful induction of atherosclerosis in rabbits. The treated rabbits showed significant protective effect by lowering the deposition of cholesterol and increasing the lumen size compared to cholesterol-fed group.

Conclusions: Phytoconstituents such as alkaloids, tannins, flavonoids, steroids, triterpenoids, and carbohydrates in the ethanolic extract may be attributed to effective anti-atherosclerotic and antioxidant activity of plant extract. Our study exhibited that EEGS extract could be a potent herbal therapeutic agent for the treatment of atherosclerosis and hypercholesterolemia-related diseases.

Keywords: Elaeocarpus ganitrus, Atherosclerosis, Hyperlipidemic, Phytoconstituents, Cholesterol, Ethanolic extract.

(c) 2017 The Authors. Published by Innovare Academic Sciences Pvt Ltd. This is an open access article under the CC BY license (http://creativecommons. org/licenses/by/4. 0/) DOI: http://dx.doi.org/10.22159/ajpcr.2017.v10i12.20111

\section{INTRODUCTION}

Hypercholesterolemia contributes significantly to the occurrence and rigorousness of atherosclerosis and cardiovascular disease that could eventually affect the majority of the adult population of developed countries [1]. The disproportion of the lipid metabolites in the affected organism is mainly accountable for these conditions. Atherosclerosis is the major lipid disorder that is characterized by endothelial dysfunction, vascular inflammation, and the buildup of lipids, cholesterol, calcium, and cellular debris within the intima of the vessel wall [2]. Further, increased oxidative stress due to Overproduction of oxygen free radicals resulting in disorders of lipid Metabolism. There is evidence to support an association between lipid oxidation and atherosclerosis development [3]. An antioxidant, which inhibits processes that lead to oxidative stress should be effective for Overwhelming atherosclerosis [4].

Several studies have established that obesity and hyperlipidemia can be induced by high-fat or high-calorie diets in the normal rodent model $[5,6]$. Herbal drugs, derivative of plant extracts, are abundantly utilized to treat a wide range of clinical diseases. Elaeocarpus ganitrus Roxb. (Syn. E. sphaericus Gaertn; family Elaeocarpaceae) which is commonly known as Rudraksha is a large evergreen broad-leaved tree. It is ethnomedicinally important plant, and different parts (seeds, leaves, and outer shell of beads) of it exhibit diverse pharmacological activities. The extensive investigation of literature exposed that E. ganitrus Roxb. is a vital source of many pharmacologically and therapeutically significant chemicals such as triterpenes, flavonoids like quercetin, tannins which include geraniin, and 3, 4, 5-trimethoxy geraniin and indolizidine alkaloids, grandisines, and rudrakine [7]. In the experimental studies, extracts of E. ganitrus showed large range of pharmacological properties such as anti-inflammatory [8], analgesic, sedative [9], hypoglycemic [10], antidepressant [11], antiasthmatic [12], antihypertensive [13], and antimicrobial [14].

Therefore, the present study is carried out to elucidate the effects of E. ganitrus on histopathology of the aorta using a cholesterol-induced hypercholesterolemic rabbit model. The outcomes of this study provide evidence to support the viability of developing E. ganitrus as a potential natural-based medicine for the treatment of atherosclerosis as well as other diseases related with hypercholesterolemia.

\section{METHODS}

\section{Collection and extraction of plant material}

Authentic seeds of E. ganitrus were obtained from Jayoti Vidyapeeth Women's University, Jaipur, and authenticated by authority of the Department of Botany, University of Rajasthan, Jaipur. A voucher specimen number (RUBL21180) was submitted at University Herbarium Department for future reference. The seeds were coarsely powdered in a cutter and grinding mill. Powdered seeds of E. ganitrus were extracted with $70 \%$ ethanol for $48 \mathrm{hrs}$, by soxhlet extraction method. Then, ethanol was filtered and evaporated to dryness at $55-60^{\circ} \mathrm{C}$ under reduced pressure in a rotary evaporator. The extract was stored in a desiccator. This $70 \%$ ethanolic crude extract of the E. ganitrus seed extract (EEGS) was dissolved in distilled water and administered to the animals through oral gavage. 


\section{Animal model}

New Zealand white male rabbits weighing $1.50-2.0 \mathrm{~kg}$ and age of 10-18 months were used in the study. The animals were acclimatized for 10 days before being used for the experiments. The animals were grouped and housed in polypropylene cages at controlled temperature $\left(23 \pm 2^{\circ} \mathrm{C}\right)$. The animals were maintained under a standard diet pellet (Ashirwad Industrial Ltd., Punjab), green leafy vegetables, and water ad libitum. The experimental protocol was approved by Institutional Animal Ethical Committee and was executed according to the guidelines of the Committee for the Purpose of Control and Supervision of Experiments on Animals, India.

\section{Experimental design}

The rabbits were divided into following groups:

- Group I: Control - placebo treated for 120 days

- Group II: Cholesterol feeding for 120 days

- Group III: Cholesterol feeding for 60 days then treated with $250 \mathrm{mg} / \mathrm{kg}$ EEGS extract for the next 60 days

- Group IV: Cholesterol feeding for 60 days then treated with $500 \mathrm{mg} / \mathrm{kg}$ EEGS extract for the next 60 days.

Cholesterol feeding: $500 \mathrm{mg}$ cholesterol//kg. b.wt./day/rabbit/day in $5 \mathrm{ml}$ coconut oil.

At the end of the treatment, all the rabbits were sacrificed; blood and aorta were collected for biochemical and histopathological examinations.

\section{Induction of hyperlipidemia}

New Zealand white male rabbits were made hyperlipidemic by daily oral administration of $500 \mathrm{mg}$ cholesterol/kg.b.wt./rabbit/day in $5 \mathrm{ml}$ coconut oil.

\section{Autopsy and fixation}

Animals were autopsied under ether anesthesia after completion of treatment. Aorta was quickly removed, cleared off the fat, and connective tissue weighed on electronic balance. A small section of the aorta of each animal was soaked in a $10 \%(\mathrm{v} / \mathrm{v})$ formocalcium solution for hematoxylin and eosin ( $\mathrm{H}$ and $\mathrm{E}$ ) staining. The aorta sections were processed for normal histological section. The tissue samples were ultrasectioned (5-6 $\mu \mathrm{m}$ thickness), stained with $\mathrm{H}$ and $\mathrm{E}$, and analyzed under a light microscope for observation of structural abnormality.

\section{Biochemical analysis}

Aorta was analyzed for total cholesterol [15], triglyceride [16], phospholipid [17], and antioxidant parameters, i.e., lipid peroxidation [18], catalase (CAT) [19], glutathione (GSH) [20], and superoxide dismutase (SOD) [21]

\section{Statistical analysis}

All values were expressed as mean \pm standard error of the mean. The data obtained were subjected to statistical analysis using one-way ANOVA followed by Tukey's multiple comparison tests by GraphPad Prism software (version 5). $\mathrm{p}<0.05$ was considered to be statistically significant.

\section{RESULTS}

Cholesterol, phospholipid, and triglyceride level of the aorta after cholesterol feeding in Group II showed elevation in comparison to the control group. However, it was found to be decreased significantly $(p \leq 0.001)$ in both the treated groups in comparison to hyperlipidemic rabbits in dose-dependent manner (Fig. 1)

Further, we found that cholesterol feeding to rabbits for 120 days produced a significant decrease in the activity of CAT, SOD, and GSH levels whereas an increase in thiobarbituric acid reactive substances (marker of lipid peroxidation) activity of aorta was observed. A dose dependent Reduction in lipid peroxidation levels, whereas an elevation In GSH content, catalase as well as SOD activity was observed after the Treatment with EEGS extract (Table 1).
The histopathological analysis of control group rabbits showed characteristic three layers of arteries without any lesion in intima or media (Fig. 2). Cholesterol-fed rabbits for 120 days depicted welldeveloped atheromatous intimal plaque. The plaque consists of lipidladen foam cells, collagenous fibers, and smooth muscle cells. The lumen size was reduced to a great extent as plaque is protruding into the lumen of the aorta when compared to control aorta. Few foam cells were also presenting in media (Fig. 3). Microphotographs of the

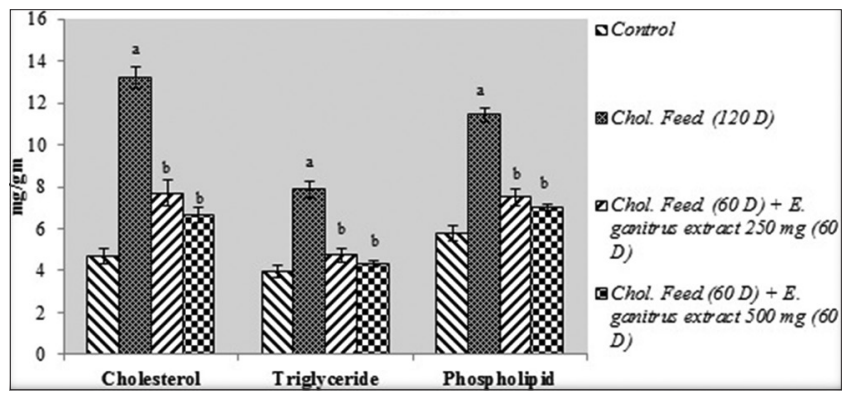

Fig. 1: Effect of ethanolic extract of Elaeocarpus ganitrus on tissue biochemistry of cholesterol-fed rabbits. *Cholesterol feeding: $500 \mathrm{mg} / \mathrm{kg}$ body weight (b.wt.) in $5 \mathrm{ml}$ coconut oil/day,

${ }^{* *}$ E. ganitrus: $250 \mathrm{mg} / \mathrm{kg}$. b.wt./day, ${ }^{* * *}$ E. ganitrus $500 \mathrm{mg} /$

kg. b.wt./day, values \pm 5 determination, ${ }^{a} p \leq 0.001$ highly significant, ${ }^{b} \mathrm{p} \leq 0.001$ highly significant Group II compared with Group I, Group III, IV compared with Group II

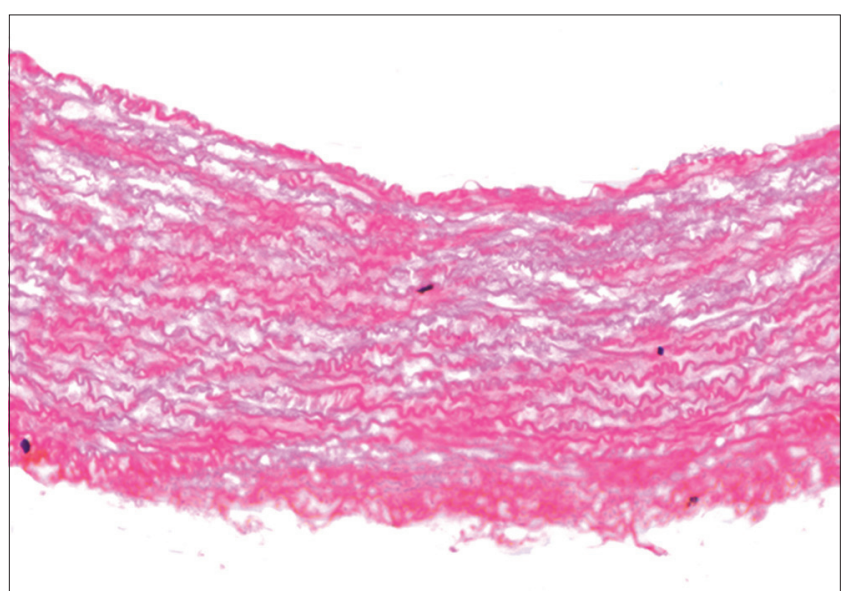

Fig. 2: Ascending aorta of control rabbit

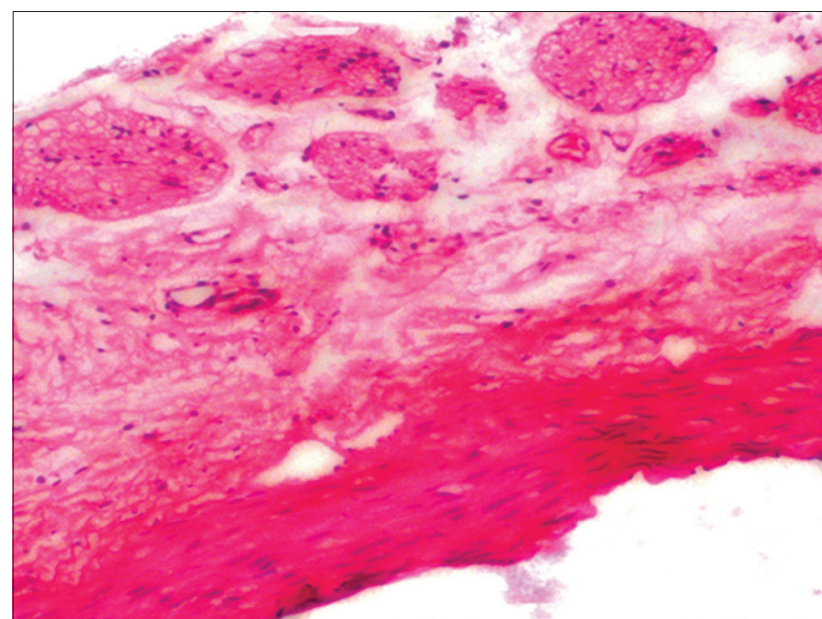

Fig. 3: Ascending aorta of rabbit after cholesterol feeding for 120 days 
Table 1: Effect of ethanolic extract of E. ganitrus on antioxidant parameters

\begin{tabular}{|c|c|c|c|c|c|}
\hline Identification & Group & $\begin{array}{l}\text { Lipid peroxidation } \\
\text { (n mole MDA/mg) }\end{array}$ & $\begin{array}{l}\text { GSH } \\
\text { (n mole/gm) }\end{array}$ & $\begin{array}{l}\text { CAT (nmole of } \mathrm{H}_{2} \mathrm{O}_{2} \\
\text { consumed/minute/mg } \\
\text { protein) }\end{array}$ & $\begin{array}{l}\text { SOD (units } / \mathrm{mg} \\
\text { of protein) }\end{array}$ \\
\hline Control (placebo treated) from day 1 to 120 & I & $0.11 \pm 0.02$ & $20.59 \pm 1.11$ & $69.95 \pm 2.07$ & $17.87 \pm 0.64$ \\
\hline Cholesterol feeding from day 1 to 120 & II & $0.79^{\mathrm{a}} \pm 0.05$ & $9.74^{\mathrm{a}} \pm 1.19$ & $43.94^{\mathrm{a}} \pm 1.43$ & $6.04^{\mathrm{a}} \pm 1.10$ \\
\hline $\begin{array}{l}\text { Cholesterol feeding* from day } 1 \text { to } 60+E \text {. } \\
\text { ganitrus ethanolic extract** from day } 61 \text { to } 120\end{array}$ & III & $0.52^{c} \pm 0.02$ & $16.63^{c} \pm 0.63$ & $55.55^{c} \pm 1.27$ & $13.76^{\mathrm{c}} \pm 1.15$ \\
\hline $\begin{array}{l}\text { Cholesterol feeding from day } 1 \text { to } 60+E \text { ganitrus } \\
\text { ethanolic extract*** from day } 61 \text { to } 120\end{array}$ & IV & $0.45^{\mathrm{b}} \pm 0.02$ & $19.55^{\mathrm{b}} \pm 0.52$ & $66.01^{\mathrm{b}} \pm 1.916$ & $15.34^{\mathrm{b}} \pm 1.21$ \\
\hline
\end{tabular}

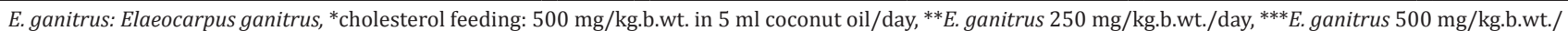
day. Values \pm 5 determination, ${ }^{\mathrm{a}} \mathrm{p} \leq 0.001$ highly significant Group II compared with Group I, ${ }^{\mathrm{p}} \mathrm{p} \leq 0.01$ significant, ${ }^{\mathrm{c}} \mathrm{p} \leq 0.001$ highly significant Group III, IV compared with Group II, ${ }^{\mathrm{d}} \mathrm{p} \leq 0.01$ significant, MDA: Malondialdehyde, GSH: Glutathione, CAT: Catalase, b.wt: Body weight, SOD: Superoxide dismutase

animals after administration of different doses of EEGS extract showed regressed intimal plaque, and three distinct layers of intima, media, and adventitia are reverting to their normal position. However, few lipid-laden cells and fibrous tissue were present in the middle layer in comparison to Group II rabbits (Figs. 4 and 5).

\section{DISCUSSION}

Plant sterols of E. ganitrus may be attributed to cholesterol lowering effect by interference in the absorption of dietary fat and cholesterol as well as improved endogenous cholesterol excretion [22]. Previous studies have shown that a high-fat diet in rats increases the long-chain acyl-CoA content in liver and red muscles. Our study further confirmed that cholesterol feeding for 120 days would increase the acyl-CoA pool, resulting into increased triglyceride storage [23]. Phytoconstituents of EEGS extract may credit to decreased level by a stimulation of the degradation of triglycerides through better expression and activity of lipoprotein lipases and to a reduction of hepatic production and excretion of triglycerides [24]. Post-treatment with EEGS extract showed considerable reduction in phospholipid levels as compared to hypercholesterolemic rabbits. This may be attributed to the improved activity of phospholipases [25].

High cholesterol, particularly low-density lipoprotein (LDL) is the major Reason attributed to cardiovascular diseases. The lipid peroxidation is aggravated by the imbalance in the lipid metabolism [26,27]. The previous study demonstrated that a decline in lipid peroxidation result in the reduction of hypercholesterolemia-induced atherosclerosis [28]. In the current study, the malondialdehyde (MDA) level was raised significantly in cholesterol-fed rabbits in comparison with the control rabbits. Experimental outcomes suggested that surplus cholesterol result in the generation of reactive oxygen species and speedy progression of lipid peroxidation, leading to tissue damage $[29,30]$. Furthermore, EEGS extract revealed preventive function against atherogenesis as it decreased the lipid peroxidative markers, MDA levels in the tissues. This could be due to the reaction of EEGS extract with peroxyl radicals including the inhibition of lipid peroxidation chain propagation [31].

A significant decrease in the levels of total GSH observed on cholesterol feeding might be due to reduced GSH biosynthesis which increased in hypercholesterolemia [32]. Cholesterol feeding followed by administration of plant extract to hypercholesterolemic animals showed a significantly elevated level of GSH. It is possible that extract might have reduced the extent of oxidative stress, leading to lesser GSH degradation or increase in the biosynthesis of GSH [33]. Furthermore, it could be due to decreases in the free radicals by quenching and lowering oxidative stress [34].

The decrease in the SOD and the catalase activities in the cholesterolfed rabbits are recognized to increased oxidative stress on cholesterol feeding in these animals [35]. EEGS extract-treated hyperlipidemic rabbits had noticeably elevated levels of SOD and CAT, reversing the ill effects of hyperlipidemia. It is well established that polyphenols and

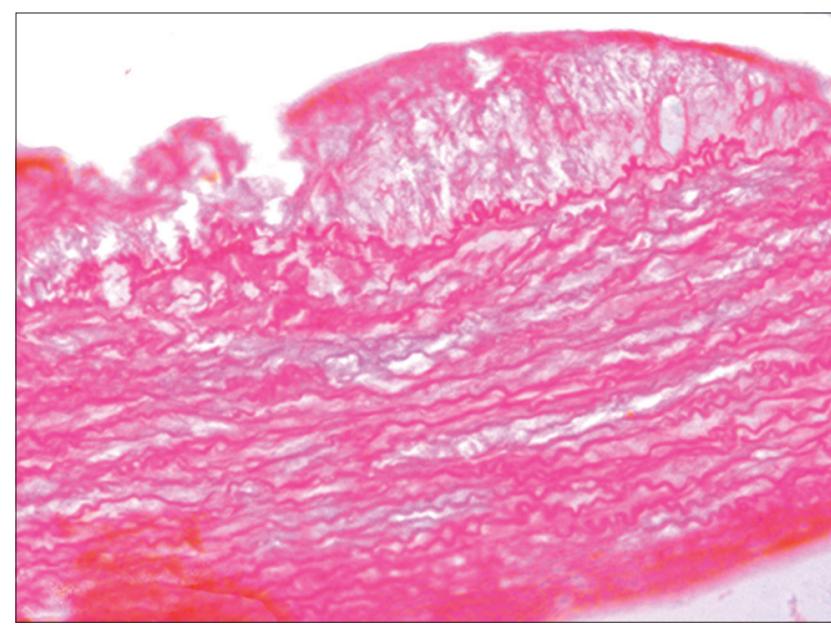

Fig. 4: Ascending aorta of rabbit - cholesterol feeding from day 1 to $60+$ Elaeocarpus ganitrus seed extract extract $(250 \mathrm{mg} / \mathrm{kg}$. body weight/day) from day 61 to 120

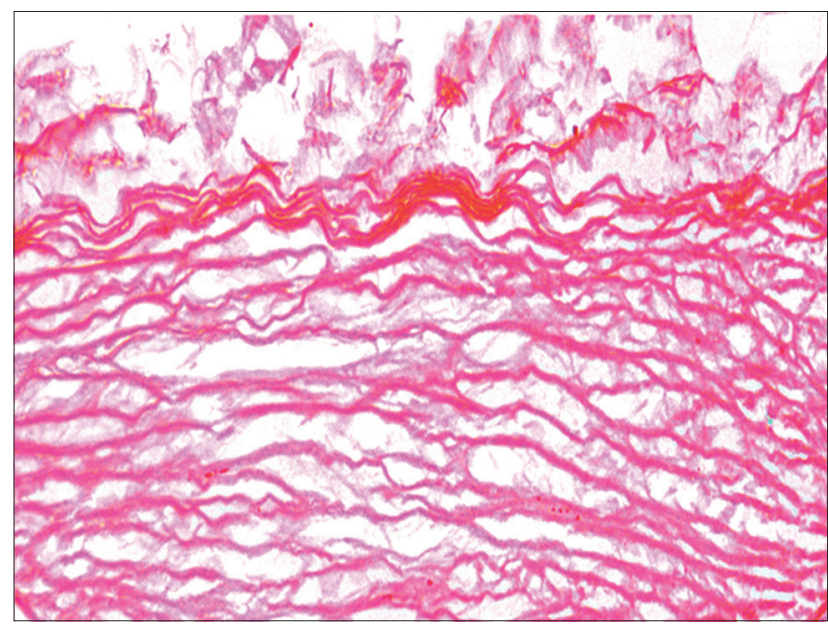

Fig. 5: Ascending aorta of rabbit - cholesterol feeding from day 1 to $60+$ Elaeocarpus ganitrus seed extract $(500 \mathrm{mg} / \mathrm{kg}$. body weight/day) from day 61 to 120

flavonoids are natural antioxidants and have also been reported to considerably increase SOD and CAT levels [36,37]. The total phenolic content in E. ganitrus was detected to be $56.79 \pm 1.6 \mathrm{mg}$ gallic acid equivalents/g of dry material. Total flavonoids in E. ganitrus were detected to be $18.58 \pm 0.3 \mathrm{mg}$ rutin equivalents/g of dry material [38]. These findings recommend $85 \%$ of the antioxidant capacity of E. ganitrus is by virtue of phenolics and flavonoid components. The presently illustrated raised levels of both SOD and CAT could be 
explained as the influence of flavonoids and polyphenols of E. ganitrus. This is in agreement with the findings of other studies in the literature for extracts of plant products [39].

Aorta is the main artery originating from the left ventricle of the heart and distributes oxygenated blood to all the body parts. The control rabbit aorta showed all the three layers, i.e., tunica intima, tunica media, and the outer most tunica adventitia. In the present study, cholesterol feeding for 120 days demonstrated atheromatous plaque when compared to control group rabbits. In hyperlipidemic rabbits, cholesterol deposits were concentrated in the media tunica and intima tunica regions, mainly in the endothelial layer. The focal thickening of the intima is due to a large increase in smooth muscle cells, formation of new connective tissue matrix by these smooth muscle cells, and in hyperlipidemic individuals, the accumulation of intracellular and extracellular lipid.

Preclinical interpretations have shown that hypercholesterolemia induces the buildup of oxLDL in the arterial wall, stimulating endothelial cell dysfunction and atherosclerosis development [40]. These substances are noxious to endothelial cells, leading in lesions that promote monocytes and macrophages to grow into foam cells, eventually resulting into atheroma [41]. A marked decrease in plaques was observed in the EEGS extract-treated groups as compared to the cholesterol-fed group. The improvement might be associated with the free radical scavenging activity of plant extract which prevents LDL oxidation. In addition, it could be due to the strong presence of sterols which stimulate bile fluid secretion as well as biliary cholesterol secretion and improve excretion of bile acids in feces [42]. Furthermore, it is well known that polyphenols have various pharmacological properties, including hypolipidemic and antiatherogenic activity [43]. The tannins and flavones may perform in free radical scavenging mechanism and may check atherogenesis in rabbit aorta $[44,45]$.

\section{CONCLUSION}

Considering all the above findings, it can be concluded that consumption of $E$. ganitrus extract might check atherogenesis. Biologically active components such as phytosterols, flavonoids, alkaloids, tannins, fats, carbohydrates, and proteins could be credited to anti-atherosclerotic property of the plant. There is a requirement of advance studies to be done for isolating the pure secondary metabolites and to study the exact underlying vascular protective mechanisms of EEGS extract. Our study demonstrated that the seed of E. ganitrus has strong cardiovascular protective effects and could be a potential candidate for the development as a herbal therapeutic for preventing atherosclerosis progression triggered by unusual lipid metabolism and oxidative stress.

\section{ACKNOWLEDGMENTS}

Authors are grateful to Department of Zoology, University of Rajasthan, Jaipur (India) for providing necessary facilities.

\section{REFERENCES}

1. Kuklina EV, Yoon PW, Keenan NL. Trends in high levels of lowdensity lipoprotein cholesterol in the United States, 1999-2006. JAMA 2009;302(19):2104-10

2. Hayashi K, Mani V, Nemade A, Aguiar S, Postley JE, Fuster V, et al. Variations in atherosclerosis and remodeling patterns in aorta and carotids. J Cardiovasc Magn Reson 2010;12:10.

3. Harauma A, Murayama T, Ikeyama K, Sano H, Arai H, Takano R, et al. Mulberry leaf powder prevents atherosclerosis in Apo lipoprotein E-deficient mice. Biochem Biophys Res Commun 2007;358(3):751-6.

4. Niki E. Antioxidants and atherosclerosis. Biochem Soc Trans 2004;32:156-9.

5. Sharma BR, Oh J, Kim HA, Kim YJ, Jeong KS, Rhyu DY, et al. Antiobesity effects of the mixture of Eriobotrya japonica and Nelumbo nucifera in adipocytes and high-fat diet-induced obese mice. Am J Chin Med 2015;43(4):681-94.

6. Lai CH, Tsai CC, Kuo WW, Ho TJ, Day CH, Pai PY, et al. Multi-strain probiotics inhibit cardiac myopathies and autophagy to prevent heart injury in high-fat diet-fed rats. Int J Med Sci 2016;13(4):277-85.

7. Khandelwal KR. Preliminary phytochemical screening. Practical Pharmacognosy. Pune: Niralli Parkashan; 2004.

8. Nain J, Garg K, Dhahiya S. Analgesic and anti-inflammatory activity of Elaeocarpus sphaericus leaf extract. Int J Pharm Pharma Sci 2012;4 Suppl 1:379-81.

9. Katavic PL, Venables DA, Rali T, Carroll AR. Indolizidine alkaloids with delta-opioid receptor binding affinity from the leaves of Elaeocarpus fuscoides. J Nat Prod 2007;70(5):872-5.

10. Hule AK, Shah AS, Gambhire MN, Juvekar AR. An evaluation of the ant diabetic effects of Elaeocarpus ganitrus in experimental animals. Indian J Pharmacol 2011;43(1):56-9.

11. Dadhich A, Jasuja ND, Chandra S, Sharma G. Antidepressant effects of fruit extract of Elaeocarpus ganitrus in force swim test. Int J Pharm Sci Res 2014;5:2807-12.

12. Singh RK, Bhattacharya SK, Acharya SB. Studies on extracts of Elaeocarpus sphaericus fruits on in vitro rat mast cells. Phytomedicine 2000;7(3):205-7.

13. Sakat SS, Wankhede SS, Juvekar AR, Mali VR, Bodhankar SL. Antihypertensive effect of aqueous extract of Elaeocarpus ganitrus Roxb. seeds in renal artery occluded hypertensive rats. Int J PharmTech Res 2009;1(3):779-82.

14. Kumar G, Karthik L, Rao KV. Phytochemical composition and in vitro antimicrobial activity of Bauhinia racemosa Lamk (Caesalpiniaceae). Int J Pharm Sci Res 2010;1:51-8.

15. Zlatkis A, Zak B, Boyle AJ. A new method for the direct determination of serum cholesterol. J Lab Clin Med 1953;41(3):486-92.

16. Gottfried SP, Rosenburg B. Improved manual spectrophotometric procedure for determination of serum triglycerides. Clin Chem 1973;19(9):1077-8.

17. Zilversmit DB, Davis AK. Microdetermination of plasma phospholipids by trichloroacetic acid precipitation. J Lab Clin Med 1950;35(1):155-60.

18. Ohkawa $\mathrm{H}$, Ohishi N, Yagi K. Assay for lipid peroxides in animal tissues by thiobarbituric acid reaction. Anal Biochem 1979;95(2):351-8

19. Claiborne A. Catalase activity In: Greenwald R, editor. Handbook of methods for oxygen radical research. Boca Raton. Florida: CRC Press; 1985. p. 283-4

20. Carlberg I, Mannervik B. Purification and characterization of the flavoenzyme glutathione reductase from rat liver. J Biol Chem 1975;250(14):5475-80

21. Das K, Samanta L, Chainy GB. A modified spectrophotometric assay for superoxide dismutase using nitrite formation by superoxide radicals. Indian J Biochem Biophy 2000;37(3):201-4.

22. Brown AW, Hang J, Dussault PH, Carr TP. Plant sterol and stanol substrate specificity of pancreatic cholesterol esterase. J Nutr Biochem 2010;21(8):736-40.

23. Ahmida $\mathrm{MH}$, Abuzogaya $\mathrm{MH}$. The effects of oral administration of green tea and ginger extracts on serum and hepatic lipid content in rats fed a hyperlipidemic diet. Pharm Lett 2009;1(1):56-64.

24. Dhandapani R. Hypolipidemic activity of Eclipta prostrata (L.) L. leaf extract in atherogenic diet induced hyperlipidemic rats. Indian J Exp Biol 2007;45(7):617-9.

25. Muthu AK, Sethupathy S, Manavalan R, Karar PK. Hypolipidemic effect of methanolic extract of Dolichos biflorus Linn. in high fat diet fed rats. Indian J Exp Biol 2005;43(6):522-5.

26. Saikrishna N, Ranganayakulu D, Gopisudheerkumar J, Vijaykumar G, Anusha M. Anti atherosclerotic activity of the ethanolic extract of the Butea monosperma leaves as alone and in combination with the atorvastatin. J Adv Drug Res 2010;1:20-6.

27. Kumar DS, Muthu KA. Ondium suffruticosum (Ging.) (Family: Violaceae) in rat fed with high fat diet. Int $\mathrm{J}$ Pharm Pharm Sci 2012;4(4):69-73

28. Mateos R, Lecumberri E, Ramos S, Goya L, Bravo L. Determination of malondialdehyde (MDA) by high-performance liquid chromatography in serum and liver as a biomarker for oxidative stress-application to a rat model for hypercholesterolemia and evaluation of the effect of diets rich in phenolic antioxidants from fruits. J Chromatogr B 2005;827:76-82.

29. Sabina EP, Rasool M. Therapeutic efficacy of Indian ayurvedic herbal formulation triphala on lipid peroxidation, antioxidant status and inflammatory mediators TNF- $\alpha$ in adjuvant induce arthritic mice. Int $\mathrm{J}$ Biol Chem 2007;1:149-55.

30. Yassa N, Razavi BH, Hadjiakhoondi A. Free radical scavenging and lipid peroxidation activity of the Shahani black grape. Pak J Biol Sci 2008;11(21):2513-6.

31. Kulisic T, Radonic A, Katalinic V, Milos M. Use of different methods 
for testing antioxidative activity of organo essential oil. Food Chem 2004; $85: 633-40$

32. Bansal MP, Jaswal S. Hypercholesterolemia induced oxidative stress is reduced in rats with diets enriched with supplement from Dunaliella salina algae. Am J Biomed Sci 2009;1:196-204.

33. Prasanna GS, Purnima A. Protective effect of leaf extract of Trichilia connaroides on hypercholesterolemia induced oxidative stress. Int $\mathrm{J}$ Pharmacol 2011;7:106-12.

34. Deepa B, Anuradha CV. Antioxidant potential of Coriandrum sativum L. seed extract. Indian J Exp Biol 2011;49(1):30-8.

35. Sethi J, Sood S, Seth S, Talwar A. Evaluation of hypoglycemic and antioxidant effect of Ocimum sanctum. Indian $\mathrm{J}$ Clin Biochem $2011 ; 19(2): 152-5$

36. Fang YZ, Yang S, Wu G. Free radicals, antioxidants and nutrition. Nutrition 2002;18(10):872-9.

37. Visavadiya NP, Narasimhacharya AV. Hypolipidemic and antioxidant activities of Asparagus racemosus in hypercholesteremic rats. Indian J Pharmacol 2005;37(6):376-80.

38. Luo XD, Basile MJ, Kennelly EJ. Polyphenolic antioxidants from the fruits of Chrysophyllum cainito L. (star apple). J Agric Food Chem 2002;50(6):1379-82.

39. Prabha SP, Ansil PN, Nitha A, Wills PJ, Latha MS. Anti-atherogenic activity of methanolic extract of Gardenia gummifera linn. on high fat diet induced atherosclerosis in rats. Int $\mathrm{J}$ Pharm Pharm Sci 2013;5(2):388-93

40. Aikawa M, Libby P. The vulnerable atherosclerotic plaque: Pathogenesis and therapeutic approach. Cardiovasc Pathol 2004;13:125-38.

41. Afonso MS, Silva AM, Carvalho EB, Rivelli DP, Barros SB, Rogero MM, et al. Phenolic compounds from rosemary (Rosmarinus officinalis L.) attenuate oxidative stress and reduce blood cholesterol concentrations in diet-induced hypercholesterolemic rats. Nutr Metab 2013;10(1):1-9.

42. Katan MB, Grundy SM, Jones P, Law M, Miettinen T, Paoletti R, et al. Efficacy and safety of plant stanols and sterols in the management of blood cholesterol levels. Mayo Clin Proc 2003;78:965-978.

43. Schneider M, Sachett A, Schönell AP, Ibagy E, Fantin E, Bevilaqua F, et al. Hypoglycemic and hypolipidemic effects of Solidago chilensis in rats. Rev Bras Farmacogn 2015;25(3):258-63.

44. Wua SJ, Lean TN. Antioxidant and free radical scavenging activities of wild bitter melon (Momordica charantia Linn. var. abbreviata Ser.) in Taiwan. LWT-Food Sci Technol 2008;41:323-30.

45. Sathishsekar D, Subramanian S. Antioxidant properties of Momordica charantia (bitter gourd) seeds on streptozotocin induced diabetic rats. Asia Pac J Clin Nutr 2005;14(2):153-8. 